\title{
INTRINSIC ELEMENT IN THE OLD MAN AND THE SEA BY ERNEST HEMINGWAY
}

\author{
Zainuddin \\ Universitas Trunojoyo Madura \\ e-mail: binsugendal@gmail.com
}

\begin{abstract}
ABSTRAK
Penelitian ini berjudul "Intrinsic Element in The Old Man And The Sea by Ernest Hemingway". The Old Man and the Sea adalah novel pendek karya seorang jurnalis dan sastrawan besar Amerika, Ernest Hemingway, diterbitkan pada tahun 1952 dan mendapat hadiah Pulitzer pada 1953 untuk karya fiksi. Pada 1954, Hemingway memenangkan hadiah nobel berkat karya terakhirnya ini. Cerita dalam novel ini sangat menginspirasi, tentang seorang nelayan yang sangat gigih bertarung untuk mendapatkan ikan marlin besar. Tujuan penelitian ini adalah untuk mendeskripsikan tokoh, latar, alur, konflik, dan sudut pandang di dalam novel The Old Man and The Sea. Metode yang digunakan dalam penelitian ini adalah metode dokumenter yang menganalisis karya-karya berbentuk dokumen. Data yang digunakan dalam penelitian ini adalah kalimat-kalimat dalam novel The Old Man And The Sea karya Ernest Hemingway dan disesuaikan dengan teori.

Hasil penelitian novel The Old Man and The Sea meliputi tokoh, latar, alur, dan sudut pandang sebagai berikut; Tokoh yang ada di dalam novel ini adalah dua orang bernama Santiago dan Manolin. Santiago digambarkan sebagai orang tua dan tidak banyak berkomunikasi dengan orang lain sedangkan Manolin digambarkan sebagai seorang bocah yang polos dan mempunyai semangat membantu Santiago, tetapi juga memiliki kebingungan karena ayahnya tidak menyukai pertemanannya dengan Santiago. Latar novel meliputi latar tempat, kebanyakan di tengah lautan, latar waktu, dan latar sosial yang beragam. Alur dalam cerpen ini memakai alur campuran atau dengan lebih dominan alur maju. Sudut pandang yang digunakan dalam cerpen ini adalah sudut pandang campuran atau omniscient.
\end{abstract}

Keywords: Ernest Hemingway, novel, unsur intrinsik. 


\section{INTRODUCTION}

The novel is an invented prose narrative that is usually long and complex and deals especially with human experience through a usually connected sequence of events. Prose style and length, as well as fictional or semi-fictional subject matter, are the most clearly defining characteristics of a novel. Unlike works of epic poetry, it tells its story using prose rather than verse; unlike short stories, it tells a lengthy narrative rather than a brief selection. There are, however, other characteristic elements that set the novel apart as a particular literary form. The novel is built by intrinsic elements and extrinsic elements. Rene Wellek (1949: 139) explained his intrinsic approach, which essentially is a study of literary work based on analyzing the internal elements. Intrinsic element is an element that builds a story from within the story itself which includes characters, point of view, setting, plot, and style. This element causes literary works present as literary works.

The Old Man and the Sea, short heroic novel by an American journalist, Ernest Hemingway, published in 1952 and awarded the 1953 Pulitzer Prize for fiction. In 1954, Hemingway won the Nobel Prize. It was his last major work of fiction. This story is very inspiring, about an old fisherman who engages in an epic battle to catch a giant marlin.

Ernest Miller Hemingway was born on July 21, 1899, in Cicero (now in Oak Park), Illinois. He was born to a couple of Clarence and Grace Hemingway. They lived in the suburbs of Chicago, but the family also spent a lot of time in northern Michigan, where they had cabins. It was there that Hemingway learned to hunt, fish and appreciate the outdoors.

In high school, Hemingway worked on his school newspaper, Trapeze and Tabula, writing mainly about sports. Soon after graduating, he began working as a journalist for the Kansas City Star, giving him experience that would later influence his prose style.

Many literary works that have been published by Ernest Hemingway include a collection of stories titled In Our Time, as well as novels like The Sun Also Rises, A Farewell to Arms, For Whom the Bell Tolls and The Old Man and the Sea, which won the Pulitzer Prize in 1953. In 1954, Hemingway won the Nobel Prize. He committed suicide on July 2, 1961, in Ketchum, Idaho.

The purpose of the study are to identify intrinsic element in The Old Man and The Sea by Ernest Hemingway. The result of this study is hopefully will be useful for the reader, the students and researcher about intrinsic element especially in The Old man and The Sea novel, both theoretically and practically. Theoretically, this research is very useful, especially forms of intrinsic element. It is also useful for further reference for those who have an interest in displaying intrinsic element. Whereas practically, for students or scholars, it will be introduced to the concept of intrinsic element, and for the reader, it is useful to avoid mistakes in understanding or using intrinsic elements. Furthermore, understanding intrinsic element in the novel or short story will make the students or readers easier to catch the meaning and massage. 


\section{RESEARCH METHOD}

The data of this study was taken from the Novel entitled "The Old Man and The Sea" by Ernest Hemingway. This Novel is chosen as data source because it is very popular and inspiring, in addition to having also won a Pulitzer Prize for fiction in 1953. The data was collected through library research that was collected through doing some steps, such as: (1) reading and understanding the whole content of the story, (2) identifying the data related to the topic and it was followed by note taking. The collected data was analyzed descriptively based on theoretical framework. First, the collected data was analyzed by classifying intrinsic element in the novel. After being classified, the data was analyzed in order to determine of the intrinsic element based on the theory proposed by Steve Alcorn (2012), Nurgiyantoro (2010), Wellek and Warren (1949).

\section{FINDING AND DISCUSSION}

Intrinsic elements, according to Nurgiyantoro in his book Teori Pengkajian Fiksi (2010) are the elements that construct the literary work itself. These elements cause literary works to be present as literary works, elements which are factually found when people read literary works. The elements that can be found when people read literature. The intrinsic elements are as follows:

\section{Characters}

A character is a person who is raised by the author in the story along with the inherent character with him, the character's behavior is also called characterization. Characterizations can usually be identified through how the character speaks and behaves. The characters are the authors' fabrication, therefore only the author knows the character. The concept of character is the most important of those dramatic elements. The characters will drive the story, so we'll devote a lot of time to exploring ways to make the characters real.

There are two characters in the novel The Old Man and the Sea, Santiago and Manollin. Santiago is portrayed as an individualistic old man and does not communicate much with others. This description is found in the following quotation.

"He had probably started to talk aloud, when alone, when the boy had left.

But he did not remember. When he and the boy fished together they usually spoke only when it was necessary." (Hemingway: 1954: 10)

As described above, he does not try to talk to others. He's the type of person who is calmer living alone. He only talks if necessary. So it's not strange if he ends up going fishing alone. But Santiago is a passionate person. He believes he can get a big fish someday and he tries to prepare for it as illustrated in the following quotation.

"But, he thought, I keep them with precision. Only I have no luck anymore. But who knows? Maybe today. Every day is a new day. It is better to be lucky. But I would rather be exact. Then when luck comes you are ready." (Hemingway: 1954: 08)

Whereas, Manolin is a kind child he actually wants to help Santiago but he refuses Manolin's offer which forces him to accompany him because Santiago knows, Manolin's parents don't really like him. It is illustrated in the following quotation 
"It was papa who made me leave. I am a boy and I must obey him." (Hemingway: 1954: 05)

From this quote, we can find out how manolin is so comfortable with Santiago but he also cannot refute his father

"When I come back, you can tell me about the baseball. The boy saw that the old man was breathing and then he saw the old man's hands and he started to cry. He went out very quietly to go to bring some coffee and all the way down the road he was crying." (Hemingway: 1954: 03)

In this quotation, from the above quotation, Manolin shows his good relationship with Santiago.

\section{Setting}

In The Old Man and the Sea, place setting is harbor and the sea. This setting guides readers to feel like that they are in the harbor or they are fishing on a boat. We can find it from the quotation

"When the wind was in the east a smell came across the harbor from the shark factory; but today there was only the faint edge of the dour because the wind had backed into the north and then dropped off and it was pleasant and sunny on the Terrace."(Hemingway: 1954: 02)

There is no precise mention of time setting. However, we can guess it from their conversation about baseball. All readers know that baseball is not played in the middle ages but played in the modern times. In addition to this, Santiago and Malnollin talk about baseball player, Joe Dimaggio who was actual player in 1950's. Readers can guess the time setting from it.

"In the American League it is the Yankees as I said," the old man said happily. "They lost today," the boy told him. That means nothing. The great DiMaggio is himself again." (Hemingway: 1954: 05)

Social setting in The Old Man and The Sea is relationship with nature especially for the old man and the ocean and fishes. The nature and the fishes were the friends in his lonely life. The old man really loves the nature and he even talked to the fishes and felt sympathy for fishes that he caught. He does not regard the nature as inanimate object but as sociable object. It became an enemy or friend. It seemed weird for the first time, but it lead me to understand how much the old man loves and values the nature and fishes. We can find it from the quotation

"The ocean is very big and a skiff is small and hard to see," the old man said. He noticed how pleasant it was to have someone to talk to instead of speaking only to himself and to the sea. "I missed you," he said. (Hemingway: 1954: 35)

\section{Plot}

According to Suminto A. Sayuti (2000: 31) Plot is defined as events that are told at length in a particular series and based on the relations of console that have a structure. The structure consists of three parts, namely the beginning, middle, and end. In this novel the series moves forward and occasionally the characters in it recount the events that happened before. For example, the Plot in the beginning is as follows 
"He was an old man who fished alone in a skiff in the Gulf Stream and he had gone eighty-four days now without taking a fish. In the first forty days a boy had been with him. But after forty days without a fish the boy's parents had told him that old man was now definitely and finally salao, which is the worst form of unlucky, and the boy had gone at their orders in another boat which caught three good fish the first week." (Hemingway: 1954: 05)

\section{Conflict}

Conflict, suspense, and mystery are ways to make your plot really grab your readers' attention. In the novel, Santiago has inner conflict. For example,

"You did not kill the fish only to keep alive and to sell for food, he thought. You killed him for pride and because you are a fisherman. You loved him when he was alive and you loved him after. If you love him, it is not a sin to kill him. Or is it more?"'(Hemingway: 1954: 29)

\section{Viewpoints}

The point of view is the position of the author in a story. This means that the author can be positioned as a character in the story or as someone who is outside the story. In this novel the point of view is using Omniscient. as said by Steve Alcorn (2012) that the Third-person omniscient viewpoint lets you describe any event, anywhere, whether a person is present or not. It also allows you to explore the thoughts of any character - or even animals - as you please. and it has been illustrated since the beginning of the story in this novel. For Example:

He was an old man who fished alone in a skiff in the Gulf Stream and he had gone eighty-four days now without taking a fish. In the first forty days a boy had been with him. But after forty days without a fish the boy's parents had told him that the old man was now definitely and finally salao, which is the worst form of unlucky, and the boy had gone at their orders in another boat which caught three good fish the first week. It made the boy sad to see the old man come in each day with his skiff empty and he always went down to help him carry either the coiled lines or the gaff and harpoon and the sail that was furled around the mast. The sail was patched with flour sacks and, furled, it looked like the flag of permanent defeat. (Hemingway: 1954: 05)

\section{CONCLUSION}

Most importantly, this novel at first glance the story looks simple. However, it has so many meanings about people and their society. The story begins with a routine at the harbor with an individualist named Santiago. He tried to catch a big fish. As a result, he can get his own satisfaction.

This story was developed by the main character, Santiago. He is considered an old fisherman and boy named Manolin who thinks that he is an unlucky fisherman when everyone does not believe he is returning with a fish. However, he was finally able to catch a large marlin alone even though sharks eat their catch.

This novel tells about the struggle with a dominant setting in the middle of the sea, and uses forward and backward paths. This novel gives so many lessons about struggle and courage. 
He is also a patient person. Santiago is confronted with many difficulties and suffering but not giving up, also friendship between Santiago and Manolin, staying well connected with mutual respect.

Finally, I suggest this novel is worth reading. Not just because this novel is famous or interesting but there is also morals and messages and even courage.

\section{REFERENCES}

Alcorn, Steve. 2012. How to FixYour Novel. Theme Perks Press

https://www.biography.com/writer/ernest-hemingway

https://www.britannica.com/topic/The-Old-Man-and-the-Sea-novel-by-Hemingway

https://www.merriam-webster.com/dictionary/novel

https://www.thoughtco.com/what-is-a-novel-4685632

Nurgiyantoro, Burhan.2010. Teori Pengkajian Fiksi. Yogyakarta: UGM Press.

Sayuti, Suminto A. 2000. Berkenalan dengan Prosa Fiksi. Yogyakarta: Gama Media.

Wellek, Rene. 1949. Theory of Literature. Harcourt, Brace and Company. Pp. 139. 